Krystyna Szelągowska

Uniwersytet w Białymstoku

\title{
The Philosophy of History in Henrik Ibsen's early works
}

The early works of Ibsen - which concentrate on historical issues from the old Norwegian past, using material from sagas, folk-tales, and songs - give us a picture of an author who is focused on a national programme. In accordance with the Romantic philosophy of history (historism), Ibsen uses its main categories of causation and explanation of the national past, mainly positing individual ideas as a major shaping force of the course of history and the impact of great personalities. At the same time, Ibsen presents the path for Norwegians to build a strong and independent nation, and the conditions that have to be fulfilled for that to happen.

Key words: nationality, Romanticism, Ibsen, historism

Among Henrik Ibsen's literary achievements, the realistic or naturalistic dramas, portraying the society he was living in, criticizing its hypocrisy, mores and sheep-like behaviour, are of paramount importance. He is seen as one of the most important protagonists of modernism (i.e. the cultural and philosophical trend responding to the transformation of European societies in the second half of the nineteenth century). "His works and he himself are often much too strictly and unambiguously associated with common sense, realism, prosaic devotion to specific details, women's emancipation, and the idea of literature being engaged in social improvement in nineteenth-century Europe, the struggle for truth in collective and individual life, political and religious liberalism, etc., etc. - this list could be continued" (Sokół 1998a: 29). Less visible seems to be the early output - works prepared in the 1850s and 1860s, which all represent Romantic tendencies in Norwegian culture. However, those plays can be seen as Ibsen's contribution to the development of modern nationalism in nineteenth-century Norway. As he said: "you cannot imagine culture separated from nationality" (Beyer 1994: 24).

The main aim of this paper is to show the conception and the scheme of history present in Ibsen's early works and to substantiate the claim that they 
reflect the Romantic notion of history - individual historism ${ }^{1}$. Ibsen's grasp of the philosophy of history current at the time will be the focus, not the extent of his being close to events, let alone the question of how he managed to use professional historical knowledge. Thus, a study of sources of this knowledge will be irrelevant, just as the question of the relations between history and fiction will be. Additionally, the links between the ideas of the history plays and the national programme will be discussed. This requires some introductory remarks about the Romantic philosophy of history and its role in forming early nineteenthcentury nationalism.

\section{Romantic historism}

In the wake of the emerging modern nationalism of the early nineteenth century, history was supposed to be an important factor identifying the uniqueness and individuality of the nation. The past - remote events and characters - embodied the spirit of the nation in its pure form.

Such ideas were the core of the German-born school of individual historicism, strongly based on German idealistic philosophy, represented by such names as Johann Gottfried Herder, Johann Gottlieb Fichte, Wilhelm von Humboldt, and Georg Wilhelm Friedrich Hegel. The most famous historian representing that school of thought was Leopold von Ranke, but generally we can talk about the entirety of Romantic philosophy of history being strongly influenced by this way of thinking; we can point to such examples as Jules Michelet in France or Thomas Babington Macaulay in England. We can also name Peder Andreas Munch and Ernst Sars as the main representatives of that school in Norway. In Poland, the equivalent would be Joachim Lelewel. The school of individual historism was in a very traditional way focused on the activity of the leading social classes, monarchs, and statesmen, in other words, it was a political history.

1 I understand the term historism (German Historismus) in the way Friedrich Meinecke presented in his memorable work: "as the coming together of the ideas of individuality and development, such that one can explain the ineffable uniqueness of an entity by showing how it came to be that way through time" (Schiffman 2011: 7) and: as the "[...] substantial theory that the historical process is not characterized by causal mechanisms, but by a fundamental contingency of all events [...]" (Lorenz 2011: 96). Although the German notion is often translated into English as "historicism" I would rather apply this word to the idea of accepting "[...] the existence of laws of history allowing for predictions and explanations in historiography” (D’Amico 2011: 243), which has been described and criticized, among others, by Karl Popper (The Poverty of Historicism, 1957). See also: Berger (2011: 23). 


\section{History and nationalism}

As Friedrich Schlegel saw it, history is the "self-consciousness of a nation" (Briggs and Clavin 1997: 187; Berger 2011: 22), which leads to the Romantic fascination with the beauty of times past, but also the role of history and the national past in shaping a modern national identity, and turning nationalism into a political notion. History provided champions of nationalism with a whole world of highly emotional symbols, legendary and real events and personalities, which could serve as model examples of patriotism and true national character. The spirit of a nation - the spirit which shaped nations, peoples, and countries' individuality - was to be found in its national past, one unspoiled by foreign influences.

In Norway, this tendency was strong also because of its peculiar situation of being a nation divided into two cultures. Since the country managed to regain its own sovereign statehood in 1814 (the personal union with Sweden should not be considered, in fact, as any limitation to this status), the question was to what extent this state is based on one, united nation? According the nineteenth century standard, the perfect form of a state was a national state - a political organization for one national unit. To achieve this, to fill it with national content and give it a national character, a nation must present a united and homogenous form. The split of the Norwegians - in terms of language and culture, a division into the land tongue (landsmål) and the literary language used by elites, the riksmål, the distance between the common people and educated groups - was seen as a painful obstacle to the nation's prosperity. The programme of building one united national culture was seen as an urgent need. To limit the distance between the two cultures, the study of the remote past, medieval, or perhaps even older, was necessary. According to Romantic philosophy of history, the true national spirit was present in the past, and tracing a nation's origins would show its real distinctiveness. National history, its revival, its study were important elements in national Romanticism, the dominant program of "nationalizing" Norwegian life and society.

In the whole of Europe, a process of forming history into a specialized, academic profession can be noticed, which was followed with a remarkable growth in book-production and in a general interest in that subject. In Norway, the professional study of history was represented by Peder Andreas Munch and Rudolf Keyser, who tried to discover the origins of the Norwegian people presenting the so-called immigration theory, according which the northern regions of Norway (particularly Helgeland, a part of historical province Hålogaland) were the cradle of the Germanic people, who started here their march southward, finally destroying the Roman Empire. Although it was not mentioned by either author, this theory had been already presented earlier by the eighteenth-century historian Gerhard Schøning (Szelągowska 1984: 73-74). 


\section{Historism in Ibsen's early dramas}

Individual historism presented the view that the subject matter of history consists of living individualities, such as persons, institutions, nations, and epochs. These individualities possess an element of meaning, uniqueness, and originality. Since every single historical period in the world's history is unique, they should be reconsidered and evaluated on their own terms only, and no universal law - like the law of human progress, an idea which was very popular in the previous period of the Enlightenment - should become a universal and timeless criterion for that assessment. History should not be seen as a part of a universal framework - every age has its own individuality, own characteristics, and usually its own task to fulfil in God's plans. This individualism was also present when historians were dealing with particular events and persons, uniqueness was always a dominant factor in their characteristics. "For the subject matter of history is ultimately the human spirit, the unique element of personality that gives individuals in history their character" (Iggers 2010: xxvi).

Historical novels, dramas, poetry, and paintings evoking historical persons and events were very popular in the Romantic period. This is also the case with Henrik Ibsen, who in the early stage of his literary career (i.e. the years 1853-1863) clearly embraced Romantic culture and tradition.

Already when living in Grimstad, Ibsen planned to write a short novel A Prisoner of Akershus - a story about Christian Lofthuus, an eighteenth-century Norwegian farmer persecuted by the Danish authorities for defending local interests and provoking unrest. Then, he wrote a poem The Normans (1849), which was also not completed, although possibly Ibsen used parts of it in the work The Warrior's Barrow. Also uncompleted was a drama about Olaf Trygvasson.

After moving to Christiania, Ibsen joined an intellectual circle the so-called "Den lærde Holland" (this name was inspired by a joke from a play by Ludvig Holberg). Among his friends there were two professional historians, Ludvig Daae and Michael Birkeland. They all read and discussed the works of Rudolph Keyser and Peder Andreas Munch, and accepted Keyser's and Munch's theories on the origins of Norway. It was no coincidence that Ibsen placed the scene of his play The Vikings in Helgeland (Ording 1927: 109-111). From a book by another Romantic historian, Ernst Sars, Udsigt over den norske historie (The Outline of Norwegian History), Ibsen took the characteristics of the situation and the leading persons from the thirteenth century, using them both in Kongs-Emnerne (Jæger 1888: 150151). Of some importance were also books of Danish historians, such as Caspar Paludan-Müller (Grevens Feide, 1853-1854), Carl Frederik Allen's collection of sources (Breve og Aktstykker til Oplysning afChristiern den Andens og Frederik den 
Førstes Historie, 1854), and Frederik Hammerich (Danmark under Adelsvoelden (1854-1859) (Koht 1954: 102-103).

Generally, we can distinguish two main types of Ibsen's historical dramas. The following plays could be included in the first group: Sancthansnatten (St. John's Eve, 1853), Kjoempehøien (The Warrior's Barrow, 1850), Gildet paa Solhaug (The Feast at Solhaug, 1856), and Hormondene paa Helgeland (The Vikings at Helgeland, 1858). These works were based on fictitious events and mostly inspired by legendary material from sagas and Scandinavian mythology, as well as partly by folk culture. In composing these plays Ibsen used material mostly from the Volsunga sagas, and family sagas - Laxdølasaga, Egils saga and Njals saga - as well as Snorri's writings. Following the Romantic preference for the rustic countryside and peasant culture, Norwegian scholars at that time scrupulously collected and studied legends, fairy tales, and folk poems and songs. The most prominent were the books of Andreas Faye and Magnus B. Landstad (Bø 1998: 210-214). In the abovementioned plays, Ibsen only partly referred to historical facts, such as in Hormondene when Hjørdis tries to persuade Sigurd to rise and fight for Harald Hårfagre’s heritage - the Norwegian crown - against Eric Bloodaxe, or in Gildet paa Solhaug, when the plot is influenced by real events connected with Audun Hugleikssøn, a Norwegian aristocrat in conflict with King Håkon V in the early fourteenth century. In his letter to the director of the Royal Theatre in Copenhagen, Ibsen described the play Hormondene paa Helgeland as showing fictitious persons and events, although using the material from Icelandic sagas. He pointed out at the end: "I wanted to show a general picture of the life in the saga's period” (Ibsen 1979: 82-83).

The second group of dramas consists of those dealing with true historical facts and in which the leading figures were historical ones. Here the principal texts are: Catilina (Catiline 1854), Fru Inger til Østeraad (Lady Inger at Österaat, 1955) and Kongs-Emnerne (The Pretenders, 1864). Catilina's story is based on true events (the so called Catiline Conspiracy, described by Salust), which took place during Sulla's dictatorship in the ancient Roman republic in first half of the first century B.C. The rest is inspired mainly by Norway's national past. Fru Inger's plot is set in the dramatic times of the early sixteenth century when Norway was threatened by Danish expansion, and some last attempts were made to save her independence. In Kongs-Emnerne, the plot refers to the conflict between Jarl Skule and King Haakon IV (Håkon Håkonsson) in the first half of the thirteenth century.

The way in which Ibsen used history in his literary output was influenced by works of the German literary historian and theoretician Hermann Hettner (18211882), mainly Das moderne Drama (1852). According Hettner a historical drama should reflect true historical reality by using historical sources, but at the same time he had a vision of historical tragedy as showing the clash of ideas, as the "antitheses lead to the tragic end" (Dawns 1946: 49-50). A historical drama should also be, ac- 
cording Hettner, "a psychological tragedy of the characters" (Woerner 1895: 41). As we are going to see, Ibsen sometimes departs from historical reality and from historical sources. For example, Catiline is in his drama presented in a more positive way than the classical sources from ancient Rome do (Beyer 1994: 11). This should be associated not only with a pure Romantic fascination with a great heroic rebel and his deeds, but also with the revolutionary spirit in Europe in 1848.

In general, Ibsen's approach to the historical past was not that of a scholar or of a historian, but of a poet. For him, the past was the setting only, a stage on which he could create and observe interesting persons, events, passions, and emotions, the tragedy of human errors and destiny. The greatness of historical plots appealed to him and gave him an opportunity to portray individuals, especially female ones. This typical feature of Ibsen's drama, his readiness to present strong and usually passionate, struggling, and devoted women was also present in his early, historical plays. Lady Inger, Hjørdis, Furia, Margit initiate the range of such personalities in his output. Many motifs, so often repeated in Ibsen's works, like for instance the problem of an illegitimate child, the antagonism between a woman's role as a wife and mother and her own destiny or will, or the drama of a man facing two strong female personalities, can be found there already. Thus, there is no wonder that the past - being only some sort of an instrument - was not necessarily treated by Ibsen carefully and with respect to historical detail.

Ibsen mentioned later that when writing Fru Inger he "did [his] utmost to familiarize [himself] with the manners and customs, with the emotions, thoughts and language of the men of those days" (Ibsen 1905: 19). However, we can say that this "utmost" did not mean searching for accurate facts. In Fru Inger, Ibsen committed several errors in presenting events: e.g. he obviously mistook one of Inger's daughters for another, and certainly the principal female character is portrayed in a somewhat misleading way. But, on the other hand, we must remember that knowledge concerning this highly complicated period in Norway's history was not so common in Ibsen's time. Only a few years later, Ludvig Daae wrote an article in which he presented the results of scholarly research in that matter (Daae 1875: 224-366). Earlier, Daae wrote a letter to Ibsen, describing all the mistakes he had made in the play (Ording 1927: 229-230). In Kongs-Emnerne, Ibsen presented a peculiar chronology - putting about 25 years of time in the play and not giving clear information about how it passed by. He also portrayed bishop Nikolas as an evil person, while historical studies show him in a much more positive way (Beyer 1994: 31). Nevertheless, as Jaeger claims, thanks to using Sars book, Ibsen managed to present his personages in a rather accurate way, in accordance with historical reality (Jæger 1888: 150). It should be also noted how Ibsen managed to portray - with outstanding intuition - the forms of perception of an illiterate medieval culture, perception based on pictures rather than words (Bø 1998: 212). 
However, all the above leaves much space for further analysis. It is not historical accuracy that matters here, but rather the way in which Ibsen presented and explained historical events.

\section{Causation}

An important feature of historical individualism was the treatment of causation. The uniqueness of historical events, personages and ages, meant that coincidence had to be accepted as a cause. The timeless laws of human nature, human emotions, passions, mistakes, and individual will were also of great importance. This led to a belief, which, at the same time, linked historical individualism to traditional historical thought, that had its origins in ancient Greece and Rome - a belief that individuals, strong personalities had a major impact on history, and that they mainly contributed to its course. In opposition to Enlightenment rationalism, Romanticism embraced a reality that could not be explained within a scientific framework; for them reality held entities that were of an unknown character, close to the magical and irrational.

\section{Ibsen: Causation - supernatural forces}

One of the most typical causes used in historical works since ancient times were supernatural forces, which gave clear information about divine will and needs. In Ibsen's plays those elements are present, giving the action a necessary dramatic force. In Hormondene we have Hjørdis, who has a close relation with the supernatural world, a world portrayed directly according to its image in sagas and mythological patterns. Also in Kongs-Emnerne these elements are present, although in a rather Christian form. Archbishop Nikolas is - because of his sins - tormented and finally taken by the devil. He also comes back as a ghost to take with him to hell the evil soul of Jarl Skule. It is obvious that such motives were used by the author as a literary device - a way to portray personages in a better and sharper way. They were not used by Ibsen as causes of events.

\section{Ibsen: Causation - history as a game}

Other ways of explaining the course of history were much more important. Misunderstandings, human errors, intrigues (in many cases organized by strong and passionate women), plots, conspiracies, and very often coincidence play a signifi- 
cant role in Ibsen's presentation of the course of events. In most cases, there were personal and emotional motives lying behind such actions: ambition, hate, the will to revenge, love, envy. Ibsen was trying to portray human nature with all its good and bad sides. Furia and Eline are trying to avenge their sister's death; Nils Lykke constructs a highly complicated political intrigue because of his personal ambitions to make a career; Bishop Nikolas thinks about shaping the country's future by a rather simple trick. His "legacy" would be a "perpetuum mobile" - an everlasting reason for internal struggle: "Her, innefor dette tynne segl ligger Norges saga for hundre år!” (Ibsen 2000: 347)2.

So, history is a game, a plot in which any single incident can change its course. Lady Inger says: "i denne natt spilles brikkespil om hele Norges rike" (Ibsen 2000: 127) ${ }^{3}$. Such a way of thinking corresponds to a feeling to be found in nineteenth-century historical thought that history sometimes is a course of events (a process) strongly influenced by human nature and coincidence at the same time.

\section{Ibsen: Causation - personalities}

In the following three historical dramas of Ibsen, which are mostly based on actual historical facts, Catilina, Fru Inger, and Kongs-Emnerne, another important factor is to be seen: the impact of an individual upon history. The Roman noble Catiline, the Norwegian noble woman Lady Inger Ottersdatter of Austråt, and finally king Håkon Håkonssøn are three figures who make history, or could have made history but failed.

Lady Inger is presented as a person whose destiny was to lead the country's struggle for freedom and independence. Realising that the present moment is crucial, she remarks: "Jeg har landets velferd i mine hender" (Ibsen 2000: 127) Referring to past events, one character in the drama, Olav Skaktavl, says that Inger could have become the leader of the Norwegian people because of her origin, wealth, character, and thus authority: "I kunne blitt den utkårne I fall I hadde villet. I stammet fra Norges eldste ætter; I hadde makt og rikdom i vente [-]" (Ibsen 2000: 130$)^{5}$.

But both Olav and Inger herself know that there was also another reason for her special role: the fact, that she was chosen by God to fulfill important tasks. Inger says: “jeg kjente Guds kraft i meg, og jeg mente hva mange har ment sidenefter,

\footnotetext{
2 “Here, under this thin seal, lies Norway's saga for a hundred years!” (Ibsen 1911: 249).

3 "I am playing to-night for the whole of Norway's land" (Ibsen 1911: 56).

4 "For I have the welfare of the country in my hands" (Ibsen 1911: 57).

5 "You could have been the chosen one had you but willed it. You came of the noblest blood in Norway; power and riches were soon to be yours; [-]" (Ibsen 1911: 61).
} 
at Herren selv hadde satt sit merke på meg og kåret meg til å stride forrest for land

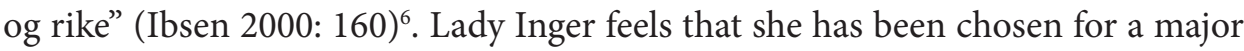
task, but she has lost her confidence and faith - and that was a main reason of her failure (Beyer 1994: 17).

In a similar way, Håkon Håkonssøn, describing his political plans, says: "Det er vervet som Gud har lagt på mine skuldre" (Ibsen 2000:357)" some other place: “jeg hører Herrens usvikelige røst rope i meg: du skal fremme et stort kongsverk i Norge!” (Ibsen 2000: 358) ${ }^{8}$.

Also Jarl Skule must finally admit, that his rival "er den, som Gud har kåret" (Ibsen 2000: 396) ${ }^{9}$.

In all these cases, one element is present: God's decision to choose a great personage to fulfil the task He wanted to be performed.

A great personage must also present other qualities. In Kongs-Emnerne, Bishop Nikolas describes an outstanding individual:

den som gør de største gjerninger, han, hvem tidens krav kommer over likesom i brynde, avler tanker, dem han ikke selv fatter, og som peker på ham på den vei han ikke selv vet hvor, bærer hen, men som han dog går og må gå [...] (Ibsen 2000: 331) ${ }^{10}$.

The great individual in history is one who embodies his own epoch, his times the one who is able to recognize (not necessarily in any rational way) the character, mission, and duty of his times in the whole process of human history designed by God himself. Such a point of view was very common in the Romantic school of historism, although we must remark that it is rather a moderate heroical theory - the great personage plays an important role, but simultaneously he or she is also shaped by the historical moment, the conditions, and the epoch's character. This opinion was expressed by Ranke himself, but also by one of his students, the outstanding Swiss historian Jakob Burckhardt, whose book Die Kultur der Renaissance in Italien was published in 1860. Such theories differed from more rigorous heroical explanations, presented for example by the British writer Thomas Carlyle (Grabski 2000: 567).

\footnotetext{
6 "I felt God's strength in me, and methought, as many have thought since, that the Lord himself had set his mark on me and chosen me to fight in the front for my country's cause" (Ibsen 1911: 139).

7 "That is the task which God has laid on my shoulders" (Ibsen 1911: 279).

8 "[-] I hear the unerring voice of the Lord calling to me: Thou shalt do a great king's-work in Norway!” (Ibsen 1911: 281).

9 "He it is whom God has chosen" (Ibsen 1911: 389).

10 " [-] that does the greatest deeds - he whom cravings of his time seize like a passion, begetting thoughts he himself cannot fathom, and pointing to paths which lead he knows not whither, but which he follows and must follow" (Ibsen 1911: 204).
} 


\section{Ideas in history}

The supreme mechanism that pushes the process of history according the Romantic school of historical individualism, something which people were not always aware of, was the idea. Ideas, as an immortal and potent force in history, came from God, and that is why they could not always be understood by humans (Gil 2011: 388). Sometimes the idea was connected with a particular mission people or some other phenomenon had to fulfil. The individual's greatness and significance were sometimes connected with their abilities to recognize the idea and the mission God had laid on him or on them. The spiritual moment is present all the time, as Ranke said: "no state has ever existed without a spiritual basis and spiritual content" (Warren 2004: 111).

This belief, that the changes in history, changes of events and processes, are due to the impact of ideas, and that this action imparts to every single phenomenon its character and uniqueness, is present in Ibsen's plays. In Kongs-Emnerne the essence of royalty, a thing which makes one man kingly and worthy of being the monarch, is the "royal idea" - "kongstanke". When Håkon Håkonsson was explaining to Jarl Skule why he could not be taken into consideration as a good king, he showed him that he lacks a royal idea that could be the spirit of his royal actions. He describes Norway metaphorically as a process of building a church, raised by Harald Fairhair and Olaf the Saint, a church which is still not complete - no consecration was performed. This blessing would happen by his own royal idea - the final unification and formation of the Norwegian nation

Ser I da ikke at Norges rike, således som Harald og Olav reiste det, kun er å ligne med en kirke som ikke har fått vigselsen ennu? [...] Jeg vil bringe vigselsen! Norge var et rike, det skal bli til et folk. [...] alle skal være ett hereafter, og alle skal vite med seg selv og skjønne at de var ett! (Ibsen 2000: 357) ${ }^{11}$.

This royal idea makes Håkon a real king. Not only he himself was aware of that; Skule has the same feeling: "Siden Håkon talte disse galmannsord [about Norway turned into one nation] står han stadig for meg som den rette konge" (Ibsen 2000: 365$)^{12}$.

This "kongstanke" cannot die, as Peter, Skule's son, says (Ibsen 2000: 374), and can excuse every deed, even the most cruel. Once again Peter declares: "En helgen

11 "See you not, then, that Norway's realm, as Harald and Olaf built it up, may be likened to a church that stands as yet unconsecrate? [-] I will bring consecration! Norway has been a kingdom, it shall become a people. [-] all shall be one hereafter, and all shall feel and know that they are one!" (Ibsen 1911: 278-279).

12 "Since Håkon spoke those madman's words, he stands ever before me a rightful king" (Ibsen 1911: 298-299). 
kunne tryggelig gjøre det [kill Håkon’s child] når min far har sagt det! Min far er konge; ti han eier den store kongstanke!" (Ibsen 2000: 394) ${ }^{13}$.

And Skule, full of pain, tormented by envy and a feeling of his own prostration, posed a dramatic question, one which had already been suggested by bishop Nikolas: "Skulle Håkon ha fått syn på de ufødte tanker?" (Ibsen 2000: 366) ${ }^{14}$, finally coming to the painful conclusion that "Kongstanken er Håkons, ikke min; han alene har fătt kraft av herren som kan gjøre den til sannhet" (Ibsen 2000: 395) ${ }^{15}$.

A great personage in history is able to understand, or perhaps to feel, ideas which exist in the spiritual world and which give every period its character. By acting, following the call of the ideas, a distinguished personality is realizing their demands and bringing into life their basic elements, thus changing reality. This is the way in which ideas push history forward.

This concept, which Ibsen put into Kongs-Emnerne, is, in my opinion, his most mature vision of historical causation. Being strongly influenced by Romanticism, Ibsen naturally presented historical events in such a light. The most popular kind of philosophy of history is also expressed in his dramas. This is also probably why Kongs-Emnerne is seen as the major achievement of this period of Ibsen's writing (Beyer 1994: 30, 34; Sokół 1998b: 129).

\section{The idea as a contributor to nation-building}

We should also notice, that the "royal idea" ("king's-thought") of King Håkon refers to the plan of uniting the Norwegians, turning them, despite differences and disputes, into one nation. This could also be seen as something which was upto-date, a contribution to the debate in Norway and the programme of building one nation, through the amalgamation of the variety of local and regional groups (Koht 1954: 203). It was, in other words, "a clear nation-building programme with a point being a combination of political nationalism of the French Enlightenment and the cultural nationalism of German Romanticism: the state as a community of law is here codified as a realm [riket]. The point is, thus, that this is not enough. A nation needs a much deeper, common base to be a people [folket]: 'the beating heart,' 'the fresh blood-flow, 'God, living spirit,' 'consecration,' being metaphors for this foundation" (Bø 1998: 215).

\footnotetext{
13 "A saint might do it unsinning, at my father's command! My father is king; for the great king's-thought is his!" (Ibsen 1911: 384).

14 "Has Håkon an eye for unborn thoughts [-]?" (Ibsen 1911: 302).

15 "The king's-thought is Håkon's, not mine; to him alone has the Lord granted the power that can act it out" (Ibsen 1911: 385).
} 
The early historical dramas of Ibsen reflect his bond with the Romantic concept of national identity and the national past. And, in fact, to some degree he never abandoned this way of thinking - as late as in the 1880s he presented a Romantic view of those matters, convinced that the Norwegian national spirit was not only unique, but was shaped by the original Norwegian nature (Moi 2006: 65, 67).

\section{Bibliography}

Berger, S. (2011). The Invention of European National Traditions in European Romanticism. In: S. Macintyre et.al. (eds.). The Oxford History of historical Writing, 1800-1945. Vol. 4. Oxford: Oxford University Press, s. 19-40.

Beyer, E. (1994). Henryk Ibsen. Transl. B. Danilszuk. Gdańsk: Wydawnictwo Gdańskie.

Bø, G. (1998). Nasjonalisme, skandinavisme og kristendom hos den unge Henrik Ibsen. In: I. Brohed (ed.). Nationalism och skandinavism i de nordiska folkkyrkorna under 1800-tallet. Lund: Lund University Press, s. 207-226.

Briggs A. and P. Clavin (1997). Modern Europe 1789-1989. A History of Europe. London: Longmann.

Daae, L. (1875). Fru Inger Ottersdatter og hendes Døttre. Historisk Tidsskrift 3: 224-366.

D'Amico, R. (2011). Historicism. In: A. Tucker (ed.). A Companion to the Philosophy of History and Historiography. Oxford: Wiley-Blackwell, s. 243-252.

Dawns, B.W. (1946). Ibsen. The Intellectual Background. Cambridge: Cambridge University Press.

Gil, T. (2011). Leopold Ranke. In: A. Tucker (ed.). A Companion to the Philosophy of History and Historiography. Oxford: Wiley-Blackwell, s. 383-392.

Grabski, A.F. (2000). Dzieje historiografii. Poznań: Wydawnictwo Poznańskie.

Ibsen, H. (1905). Letters of Henrik Ibsen. Transl. J. Nilssen Laurvik and M. Morison. New York: Fox, Duffield and Company.

Ibsen, H. (1911). The Works of Henrik Ibsen. Vol. 7-8. Transl. Ch. Archer and W. Archer. New York: Charles Scribner's Son, https://babel.hathitrust.org/cgi/pt?id=iau.31858009741608\& view $=1$ up\&seq=9 (access: 9.08.2020).

Ibsen, H. (1979). Brev 1845-1905, Ny samling. Vol. 1: Brevteksten. Oslo: Universitetsforlaget.

Ibsen, H. (2000). Samlede verker. Vol. 1. Oslo: Gyldendal.

Iggers, G. (2010). Introduction. In: L. von Ranke. The Theory and Practice of History. Transl. W.A. Iggers. New York: Routlegde.

Jæger, H. (1888). Henrik Ibsen 1828-1888. Et littercert Livsbillede. Kjøbenhavn: Gyldendal.

Koht, H. (1954). Henrik Ibsen. Eit diktarliv. Vol. 1. Oslo: H. Aschehoug \& co.

Lorenz, Ch. (2011). Scientific Historiography. In: A. Tucker (ed.). A Companion to the Philosophy of History and Historiography. Oxford: Wiley-Blackwell, s. 393-403.

Moi, T. (2006). Ibsens modernisme. Transl. A. Øye. Oslo: Pax Forlag A/S.

Ording, F.R. (1927). Henrik Ibsens Vennekreds. Det Lorde Holland. Et kapitel av norsk kulturliv. Oslo: Grøndahl \& søns boktrykkeri.

Schiffman, Z.S. (2011). The Birth of the Past. Baltimore: John Hopkins University Press.

Sokół, L. (1998a). Ibsen - mit osobisty. Konteksty. Sztuka ludowa 52 (3/4).

Sokół, L. (1998b). Peer Gynt jako wyzwanie. Dialog 43 (11). 
Szelągowska, G. (1984). Narodowość i naród w romantycznych koncepcjach norweskiej szkoły historycznej. Przegląd Zachodni 40(1): 63-85.

Warren, J. (2004). The Past and its Presenters, an Introduction to Issues in historiography. London: Hodder \& Stoughton Educational.

Woerner, R. (1895). Henrik Ibsens Jugenddramen. München: C.H. Beck. 